\title{
Agency Cost in India Banks
}

\author{
Sanjeev Acharya \\ Dept. of Finance, University of Waikato \\ Private Bag 3105, Hamilton 3240, New Zealand \\ Tel: 64-(7)-838-4466 Ext: $8183 \quad$ E-mail: Sanjeev.acharya@gmail.com
}

\begin{abstract}
Dr. Geeta Dupatti
Dept. of Finance, University of Waikato

Private Bag 3105, Hamilton 3240, New Zealand

Tel: 64-(7)-838-4756 E-mail: geetad@waikato.ac.nz
\end{abstract}

\author{
Professor Stuart Locke (Corresponding author) \\ Dept. of Finance, University of Waikato \\ Private Bag 3105, Hamilton 3240, New Zealand \\ Tel: 64-(7)-838-4756 E-mail: smlocke@waikato.ac.nz
}

Received: May 15, 2015

doi:10.5296/ifb.v2i1.7917
Accepted: June 20, 2015

Published: June 28, 2015

URL: http://dx.doi.org/10.5296/ifb.v2i1.7917

\begin{abstract}
Agency cost in Indian banks for the period 2005 to 2013, covering pre-financial crisis, crisis and post-crisis period is empirically examined in the article. It is found that the agency costs, using two measures, vary from one bank to another and change over time. The likelihood of agency cost differing between types of banks indicates that there is a low level of consistency in the results. The choice of metric used is observed to be important as different measures produce different results. The findings also indicate there is low time invariance with respect to agency costs. The source of the agency cost is attributed, at least in part, to the governance of banks during the period analysed.
\end{abstract}

Keywords: Agency cost, Performance, Banks, India, Governance, Persistence 


\section{Introduction}

This paper investigates the presence of agency costs in Indian banks. The topic is both important and timely as the Government of India (GOI) moves to partially sell down its shareholding in State-owned banks. This is viewed in the context of the GOI's packages of reform being promulgated by the Government and driven by the desire to bring many State banks into line with Basel 3 requirements without massive equity injections from taxpayers. Various issues concerning the measurement of conventional principal-agent (PA) costs in financial institutions are reviewed and two metrics are applied in the study.

The analysis is quantitative and empirical utilising secondary data sourced from the Reserve Bank of India (RBI). Initially, the questions asked are whether all banks are the same in relation to agency cost variables and to what extent they are similar within groupings of banks, e.g. private banks, State banks and foreign banks? The stability of agency cost over time is tested and also whether some banks consistently have higher agency costs than others investigated.

\subsection{Background}

The backdrop to the recent reforms in Indian banking is very long with cultural and institutional forms that have developed through an extensive history. The GOI announced that State-owned banks needed to raise private equity in order to meet providential standards and could not rely on GOI injections of capital (Reuters, 2014). A few days later the process for appointing directors to State-owned banks was changed. This policy change may have been prompted by earlier media coverage just prior to the previous national election numerous key positions were given to people associated with the then government, which soon became the opposition. The GOI announcement has indicated that the selection process for directors of State banks will be more transparent with an emphasis on core competencies and experience in the financial sector. An address by the deputy governor of the RBI six weeks prior to these GOI announcements noted that one of the key risk factors in the banking sector is directors who are unaware of the risks in their complex product mixes and a lack of knowledge about how their bank actually operates.

The manner in which GOI announced its next policy change is indicative of some of the cultural and value differences in India compared to some other large economies. GOI believes that all Indians should have a bank account and that there are a range of good reasons for why this is important such as it should help to lower corruption etc. The Prime Minister at the time of making a a statement to this effect wrote to all staff of all banks in India soliciting support for the policy. The RBI moved rapidly to simplify the requirements for opening a bank account, reducing evidentiary requirements to one form rather than the multiple documents previously required. These rapid changes with potentially far reaching impacts are part of the post-independence (1948) banking changes which included nationalisation in 1971, liberalisation in 1991, further steps in 2001 and now the movement to a mixed ownership model. However, the social agenda, which is deep-rooted in the policy and regulatory framework for banking, remains. 


\section{Macrothink}

Banking in India has existed for a long time with references to be found in ancient literature. Two and half thousand years ago advice was offered on with whom banking should be conducted, (Manu Smitri), "a sensible man should deposit his money with a person of good family, good conduct, well-acquainted with law, wealth and honourable." Chanakyas Arthashastra (about 300 B.C) is full of facts to show that there were powerful guilds of merchant bankers in existence who received deposits, advanced loans and carried on the other banking functions. In more modern times the key elements of Indian banking relate to independence, nationalisation and liberalisation and further reforms from time to time.

The rich history of banking and the number of reports and investigations on one hand make for interesting reading and on the other reveal the deep rift between commercial orientation and social need. Several sectors have from time-to-time been given a priority emphasis by Government and requirements have been imposed upon banks to provide more liberal finance. This may take the form of a specific quota, lower interest rates and/or more favourable credit appraisals. The balance sheet of banks with high levels of non-performing loans is a good indication of the problem.

\subsection{Current Bank Structure}

Indian banks currently consist of three major groups, as depicted in Figure 1, viz. public sector banks, [State Bank of India (SBI) \& associates and nationalised banks], private sector banks and foreign banks. The sector is overseen by RBI which promulgates reserve requirements, interest rate requirements to effect monetary policy and guidelines concerning governance in banks. The banks are the largest provider of debt finance in India to individuals in the form of mortgages and loans and to the commercial sector, including public sector enterprises.

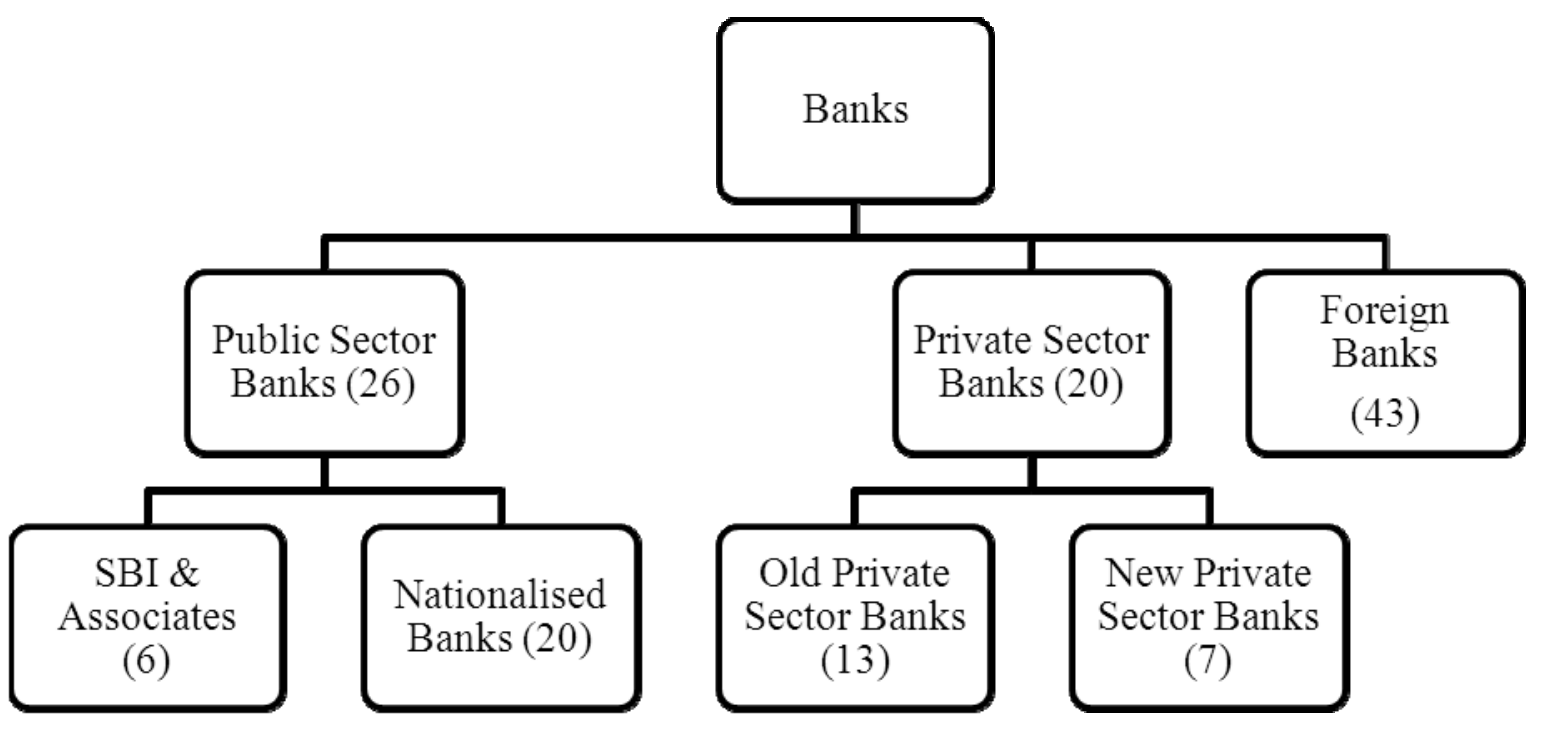

Figure 1. Types of banks in India (RBI, 2014) 
Almost all lending is in the form of floating rate loans. There is an active Money Market, but both the Bond Market and Interest Rate Futures Market lack depth (Asifma, 2013; Gupta, 2014). RBI has been encouraging banks to use 7 and 14 day interbank lending rather than overnight lending to settle cash shortages and surpluses (RBI, 2011). Some traction has been gained in promoting these longer settlements which may in turn create more hedging and fixed rate awareness. However, as profitability is simplified for the banks by their establishing their individual base rate, reflecting the RBI official rate and then adding risk a premium for each client there is little drive for change.

The public sector banks are the majority lenders to GOI, State and local governments, including trading and non-trading enterprises. It was noted by Locke and Duppati (2014) that State banks were buying significant portions of shares sold by GOI through its partial privatisation of larger public sector enterprises. They also quote the then Minister for Finance saying that if banks have surplus funds, then they should be buying more shares in Government enterprises. It would appear that this type of thinking is not reflected in the new GOI's thinking, but it is indicative of the close use of banks as a tool of government. Due to this reason, compared with private sector banks, these public sector banks are playing a dominant supplementary role in implementing government programmes, such as giving additional facilities to priority sectors. (Chaudhary \& Sharma, 2011). Similarly, Goel and Rekhi (2013) comparative study of public and private sector banks in India concludes that the performance of public sector banks is low compared to private sector banks. This topic has become more interesting due to the announcement from GOI that all the public sector banks should collect any additional capital requirements from selling shares in the Stock Market rather than rely on government support.

A comprehensive dataset of all the banks for nine years (2005-2013) has been collected for this study. The ANNOVA is used to compare the means of variables between the banks, persistence tests is used to find the continuity of variables year on year and the regression analysis is used to explore the relationship between the agency cost and banks performance.

\section{Literature Review and Hypothesis}

The early conception of agency theory, as expressed by Smith (1976, p. 233) observes that:

The directors of such companies however being the managers rather of other peoples' money than of their own, it cannot well be expected, that they should watch over it with the same anxious vigilance.

Subsequently, the idea has been developed and refined. The seminal article of Jensen and Meckling (1976) observes that agency cost arises due to the separation of ownership and control in an organisation and their research provided an impetus for many subsequent empirical studies. The majority of the analyses reported in the literature excludes financial institutions due to their financial structures, e.g. balance sheets, differing from those in other industries.

In addition to the different financial structure and income generating categories, the banking industry provides a unique scenario for agency cost due to the existence of public regulation 
(Mercado-Mendez \& Willey, 1995).

\subsection{Principal-Agent Conflict}

Principal-agent conflict arises when desires and goals of the principles and agents are not the same, i.e. a lack of goal congruence. The agency problem occurs in companies where managers take direct or indirect financial benefits at the expense of maximising shareholders' wealth (Banchit, Boulanouar, Wellalage, \& Abidin, 2013). It is suggested this situation arises as a result of conflicting interests among managers and owners and asymmetric information (Chrisman, Chua, \& Litz, 2004). However, these differences can be minimized in several ways. Crutchley and Hansen (1989) have identified that increasing managerial stock ownership, increasing dividends and increasing leverage will help to reduce the agency cost associated with the principal and agent. They note that companies with more disperse ownership are likely to face more serious problems of PA conflict. Ang, Cole, and Lin (2000) use the ratio of operating expense to total sales. Similarly, Banchit et al. (2013) use the same variable. The suggestion that increasing debt in a business reduces agency cost by restricting discretionary cash flow available to managers and through increased monitoring by debt-holders has promoted some further metrics. In the case of banking, with dispersed deposit holders, this may not hold and the providential ratios of Basel 3 accord are more appropriate and these are monitored by a country's central banks.

While reviewing the existing literature, the relationship between agency cost and bank performance in India has not been explored. However, there is research investigating agency cost and performance in nonfinancial sectors of Indian companies.. The study of Locke and Duppati (2014) explores the relationship between the agency cost and corporate governance mechanism in Indian state- owned companies and privately owned companies. Similarly, (Rakesh, 2013) studies the capital structure in Indian public companies, revealing that agency cost are significantly different when a firm has higher debt to assets ratio. Bhattacharyya (2005) explores the relationship between agency cost and foreign institutional investors in India, finding that foreign institutional investors are effective monitors in reducing agency cost.

Prior research into agency relationships in banks by Mercado-Mendez and Willey (1995), England (1988), Neate (1990), Bharath (2003), Palia (2007) does not include empirical work for India.. India as an important emerging economy requires an efficient financial system and the issue of agency cost is of importance.

\subsection{Proxies for Agency Cost}

To test the existence of the agency cost in organisations, various metrics have been proposed. Multiple variations with slightly different ratios abound and the general thrust is reflected in the Table 1.

Several variables are proposed in the literature for measuring agency cost. Two variables for which data are available for all banks for the chosen eight years, covering the pre-, actual, and post-global financial crisis period, are the ratio of operating expenses to interest income and operating expenses to total loans. These are appropriate for a financial institution and are 
readily recognisable as reflecting efficiency of management.

Table 2. Metrics selected for this study

\begin{tabular}{|c|c|}
\hline Measure of Performance & Measure of PA Agency \\
\hline ROA & Operating Expenses to Interest Income \\
\hline NET NPA ratio & Profit per employee \\
\hline
\end{tabular}

All the banks may be equally prone to agency costs or there may be some variation. It is possible that some banks consistently have lower agency costs than others and the relationship between agency cost and financial performance may or may not be pronounced. A series of hypotheses are proposed and examined to address the nature of the various relationships.

\subsection{Hypotheses}

Agency theory, in addition to being a widely accepted finance model, is compatible with other approaches to business performance. For the purpose of this study the testable hypotheses fit within the agency theory model and are directly related to the research question.). Agency cost arise when principal and agent have conflicting interests and agents pursues ytheir own goals at the expense of the principal. The role of the board in the agency framework is to reduce agency costs ensuring the principals goals are pursued. This implies that the corporations performance will improve as there is less leakage into inefficiencies related to management (agent) not zealously pursuing the owners' goals.

The hypotheses are formulated as two-sided tests where the null suggests there is no difference between variables or groups of variables. The first three hypotheses are examined using an ANOVA. The fourth also uses ANOVA on the persistence data which is explained below.

$\mathrm{H}_{1}$ : All banks have the same agency cost.

$\mathrm{H}_{2}$ : All banks in the same category, i.e. State owned, Private or Foreign have the same agency costs.

$\mathrm{H}_{3}$ : Agency costs for banks do not change over time.

$\mathrm{H}_{4}$ : There is a persistence of agency costs across time for banks.

\section{Data and Methodology}

\subsection{Data}

The study uses secondary data drawn from RBI publication sources at http://dbie.rbi.org.in/DBIE/dbie.rbi?site=statistics and listed in References. The period 2005 to 2013 covers years prior to, during and after the global financial crisis. 


\subsection{Method}

The data were downloaded from the RBI website and checked for completeness. A Grubbs test was used to check for outliers and the possibility of missing observations is screened in Stata as $\operatorname{lnLIQ}$.

A single factor ANOVA is appropriate for examining whether all the banks have the same ratio scores used for in hypotheses 1 to 3. This form of analysis tests a hypothesis that each sample is drawn from the same underlying probability distribution against an alternative hypothesis that the underlying probability distributions are not all the same.

\subsection{Non-Parametric Tests / Persistency Test}

The non-parametric test was conducted to find the persistency in the agency costs of various groups of banks. A contingency table for each of the two measures used in this study was constructed and two non-parametric tests were carried out to test the persistence of these agency cost metrics. The two tests were the Z-test, proposed by Malkiel (1995), and the cross product ratio test developed by Brown and Goetzmann (1995). In order to conduct these tests, we classified the banks as banks as winners (W) or losers (L) depending on their performance level, above or below the median value during each year.

The null hypothesis for all these tests was that there is no persistence in performance of banks. In the Malkiel (1995) test, no persistence means that there is equal probability (i.e. 0.5) for past winners to be either a winner or loser in the next year. The test is calculated by using the following formula:

$$
M=\frac{(W W-(W W+W L)+0.5)}{\sqrt{(W W+W L)+0.5+0.5}}
$$

where,

$\mathrm{WW}=$ Winner for previous year and current year;

$\mathrm{WL}=$ Winner this year and loser in previous year;

and it also follows the standard normal distribution.

Similarly, for the (Brown \& Goetzmann, 1995) the null hypothesis is that the number of the banks changing the category (from winner to loser or vice versa) for the next period is equal to the number of banks remaining in the same category. To test this hypothesis we have used the cross product ratio (CPR):

$$
\mathrm{CPR}=\frac{(W W+L L)}{W L+L W}
$$

The values of CPR greater than unity refer to persistence and the values which are smaller than unity refer to non-persistence. To test the statistical significance of the values, the following Z-test is conducted: 


$$
\mathrm{Z}=\frac{\ln C P R}{\sigma \ln C R R}
$$

Where,

$$
\sigma \ln (C P R)=\sqrt{\frac{1}{W W}+\frac{1}{L L}+\frac{1}{W L}+\frac{1}{L W}}
$$

\subsection{Interpretation of ANOVA}

Principal Agent Agency Problem

The first hypothesis addresses the question of whether all banks have the same agency cost:

$\mathrm{H}_{1}$ : All banks have the same agency cost.

ANOVA calculates an $\mathrm{F}$ statistic, which provides a range of critical values for determining the confidence level for not rejecting each null hypothesis. The number of observations and variables involved are components of the calculation. Two variables are used as metrics for agency cost, the ratio of:

1) operating expenses to interest income and;

2) operating expenses to total loans.

The calculated F statistic and the F critical values are shown in Table 3.

The hypothesis is not accepted at the $1 \%$ significant level for either metric. This is not surprising as it is intuitively unlikely that agency costs are the same across all banks, which is what the ANOVA indicates.

Within specific groups such as private banks or State banks or foreign banks there might be greater similarities in agency costs. This would imply that the level of governance is uniformly the same across a category or group in terms of a board's capacity to control management. When considered in this formulation of the issue, the answer of uniformity looks less likely. Hypothesis two addresses this issue.

$\mathrm{H}_{2}$ : All banks in the same category, i.e. State owned, private or foreign have the same agency costs.

Consideration of the F statistic reported in Table 4 presents a different picture to that in Table 3 , where the null hypothesis was not accepted at the $1 \%, 5 \%$ or $10 \%$ levels. When the ratio of operating costs to income expense is the metric chosen to reflect agency cost, the hypothesis that all the new private banks have the same level of agency cost is not rejected (accepted). It is similarly the case for the State Bank of India and its Associates (SBI\&A). The operating expenses-to-total-loans metric does not reject the null hypothesis for SBI\&A. This is not a suggestion concerning the performance of SBI\&A or the level of its agency cost. It is indicating that they are all similar, which might be similarly low, similarly high or similarly somewhere in between. The ranking of the category of banks and individual banks in terms of 
their agency costs is discussed below in relation to Table 7 .

If governance improves in banks then the level of agency costs will reduce. At the broadest level we can consider whether agency costs across banks alter over time. Hypothesis 3 is formed around this issue.

$\mathrm{H}_{3}$ : Agency costs for banks do not change over time.

The test for this hypothesis is to consider the time series for an agency cost metric and check whether they are the same in each period. The results for this formulation of the ANOVA are reported in Table 5. It is apparent that we cannot reject the hypothesis at even the $10 \%$ significance level.

This lack of improvement in reducing agency costs at the aggregate level may not be the same for all categories of banks. Accordingly, the hypothesis is tested on each of the categories of banks and the statistics are reported in Table 5. It is apparent that the hypothesis of constancy of agency cost across time cannot be rejected.

An alternative approach is to consider persistence in agency costs across time.

\subsection{Persistence Test Interpretation}

In order to assess the persistency of agency cost in various groups of banks through time, the approach developed by Malkiel (1995) and (Brown \& Goetzmann, 1995) using a Z-test is conducted.

$\mathrm{H}_{4}$ : There is a persistence of agency costs across time for banks.

The results of the persistence test for all the variables taken for study are shown in Table 6 below:

The persistence test results for the Malkiel Z-test and B\&G Z-test are significant at a 99\% confidence interval for both metrics used for study. Accordingly, the hypothesis is not rejected. It can also be said that there is a significantly higher probability ( $89 \%$ and $91 \%$ for variable OEII and OETL respectively) that the past winners will remain winners for the next period. This result is likely to be the result of the banks' strategic decision making in relation to investing lending and the measures they take to reduce operating expenses.

\subsection{Coefficient of Variation of Agency Costs}

For each category of bank it is interesting to consider the average level of agency cost. The mean, i.e. average performance could be a useful measure but it is appropriate also to consider the dispersion of agency costs in banks; the standard deviation captures this effect. The quotient of standard deviation divided by the mean, known as the coefficient of variation $(\mathrm{CoV})$, is a useful statistical measure of the level of the agency costs adjusted for dispersion:

$\mathrm{CoV}=$ Standard deviation of agency cost metric/mean of agency cost.

This measure works for ratio scale units and where the distribution is log normal, the $\mathrm{CoV}$ will exhibit stationarity. 
In Table 7 these statistics are shown for the categories of banks and ranked from 1-5, where 1 is the best result and 5 is the worst.

There are features in Table 7 that warrant discussion. The first observation that might be made is that the nationalised banks are the poorest performers on both metrics whereas the SBI\&A is impressive on both. The CoVs for operating expenses to total loans are very similar for four of the five categories of banks. Operating expenses to interest income shows a greater spread in COVs. The size of non-performing loans is likely to have contributed to the difference between the two metrics. The result of government controls/policies requiring that loans are to be made available to troubled sectors where collection becomes a problem will impact on agency cost metrics. The GOI announced in August 2014 a requirement for banks to set about collecting the biggest of these non-performing loans. Any reduction in non-performing loans and/or recovering non-performing loans is going to increase operating costs.

The number of foreign banks has changed over the period and those operating have a clearly definable difference in approach from other banks. The services offered are narrower and are seen to be high value-add services rather than provision of savings accounts to poorer rural beneficiaries.

\section{Summary}

The analysis indicates that there are distinguishable differences in agency costs across banks in India, most notably across categories of banks. The agency costs were not declining over time and the persistence testing shows that almost $90 \%$ of banks did show an improvement.

The size of the non-performing loan component, the capping of interest rates and other forms of regulatory or directive intervention by GOI over the period can be mounted as a defence for the poor control of costs. However, as almost all banks are in the same position this does not explain why some banks were not improving vis à vis other banks.

Potentially, there is a massive cartel across all categories of banks to maintain agency costs, or there is something less extreme. The drive to perform in a fixed interest rate environment where some loss leader sectors must receive loans does in part limit the extent of competition. However, the results, in particular for the nationalised banks, are troubling and indicate a lack of commercial drive. Governance in such banks appears to be limited to attendance at meetings and very little strategizing about how to become a leading bank with better outreach than most other banks. Again, this may be justified by the high level of political interference and the fact that account holders are required to pay directors' fees in order to fund a totally ineffectual buffer between management and politicians, except to the extent of promoting a charade of independence for a supposed commercial undertaking.

The conclusion drawn from the analysis suggests that there is very weak governance in banks. Changes introduced in mid-2014 by the GOI regarding how directors are to be chosen and the selection of senior managers is consistent with these results. 


\section{References}

Ang, J. S., Cole, R. A., \& Lin, J. W. (2000). Agency costs and ownership structure. The Journal of Finance, 55(1), 81-106. doi:10.1111/0022-1082.00201

Asifma. (2013). Indian bond market roadmap. Asifma. Retrieved from http://www.asifma.org/uploadedfiles/news/asifma\%20-india\%20bond\%20market\%20ro admap\%20draft_wcover.pdf

Banchit, A., Boulanouar, Z., Wellalage, N. H., \& Abidin, S. Z. (2013). Relationship principal-agent or principal-principal conflicts and islamic banks" performances Business \& Management Quarterly Review, , 4, 8-16.

Brown, S. J., \& Goetzmann, W. N. (1995). Performance Persistence. The Journal of Finance, 50(2), 679-698. doi:10.1111/j.1540-6261.1995.tb04800.x

Chaudhary, K., \& Sharma, M. (2011). Performance of Indian public sector banks and private sector banks: A comparative study International Journal of Innovation, Management and Technology, 2(3), 249-246.

Chrisman, J. J., Chua, J. H., \& Litz, R. A. (2004). Comparing the Agency Costs of Family and Non-Family Firms: Conceptual Issues and Exploratory Evidence. Entrepreneurship Theory and Practice, 28(4), 335-354. doi:10.1111/j.1540-6520.2004.00049.x

Crutchley, C. E., \& Hansen, R. S. (1989). A Test of the Agency Theory of Managerial Ownership, Corporate Leverage, and Corporate Dividends. Financial Management, 18(4), 36-46. doi:10.2307/3665795

Florackis, C. (2008). Agency costs and corporate governance mechanisms: evidence for UK firms. International Journal of Managerial Finance, 4(1), 37. doi:10.1108/17439130810837375

Goel, C., \& Rekhi, C. B. (2013). A comparative study on the performance of selected public sector and private sector banks in india Journal of Business Management \& Social Sciences Research, 2(7), 46-56.

Gupta, N. D. (2014, 13 Feb). RBI pressures banks to trade bond futures. Reuters. Retrieved from

http://in.reuters.com/article/2014/02/13/india-cbank-bond-futures-idINDEEA1C067201 40213

Jensen, M. C., \& Meckling, W. H. (1976). Theory of the firm: Managerial behavior, agency costs and ownership structure. Journal of Financial Economics, 3(4), 305-360. doi:10.1016/0304-405X(76)90026-X

Locke, S., \& Duppati, G. (2014). Agency costs and corporate governance mechanisms in Indian state-owned companies and privately owned companies - a panel data analysis.

Malkiel, B. G. (1995). Returns from Investing in Equity Mutual Funds 1971 to 1991. The Journal of Finance, 50(2), 549-572. 
McKnight, P. J., \& Weir, C. (2009). Agency costs, corporate governance mechanisms and ownership structure in large UK publicly quoted companies: a panel data analysis. The quarterly review of economics and finance, 49(2), 139-158. doi:10.1016/j.qref.2007.09.008

Mercado-Mendez, J., \& Willey, T. (1995). Agency costs in the banking industry: An examination of ownership behavior, leverage and dividend policies. Journal of Economics and Finance, 19(3), 105-117. doi:10.1007/BF02920617

RBI. (2011). Report of the working group on operating procedure of monetary policy Mumbai: Reserve Bank of India Retrieved from http://rbidocs.rbi.org.in/rdocs/PublicationReport/Pdfs/PMP150311F.pdf.

RBI. (2014). A profile of banks 2013-13. India: Reserve Bank of India Retrieved from http://rbidocs.rbi.org.in/rdocs/Publications/PDFs/APB30091213F.pdf.

Reuters. (2014, 25 July). 'Risk-free' rating raises questions for Indian bank capital Financials. Reuters. Retrieved from http://www.reuters.com/article/2014/07/25/emergingmarkets-bonds-idUSL4N0Q01SU2 0140725

Singh, M., \& Davidson Iii, W. N. (2003). Agency costs, ownership structure and corporate governance mechanisms. Journal of Banking and Finance, 27(5), 793-816. doi:10.1016/S0378-4266(01)00260-6

Smith, A. (1976). An inquiry into the nature and causes of the wealth of nations (Vol. 10). London: Metheun \& Company.

\section{Appendix}

Table 1. Variables used in prior studies

\begin{tabular}{|l|l|l|}
\hline \multicolumn{1}{|c|}{ Topic } & \multicolumn{1}{|c|}{ Researcher } & \multicolumn{1}{|c|}{ Variables to measure agency cost } \\
\hline $\begin{array}{l}\text { Agency costs in the banking } \\
\text { industry: An examination of } \\
\text { ownership behavior, leverage and } \\
\text { dividend policies }\end{array}$ & Wercado-Mendez and & $\begin{array}{l}\text { Earnings volatility } \\
\text { Bank size } \\
\text { Managers' diversification of losses } \\
\text { Flotation costs }\end{array}$ \\
\hline $\begin{array}{l}\text { Agency costs and ownership } \\
\text { structure mechanisms: }\end{array}$ & Ang et al. (2000) & $\begin{array}{l}\text { Ratio of operating expenses to annual sales } \\
\text { Ratio of annual sales to total assets }\end{array}$ \\
\hline $\begin{array}{l}\text { Agency costs and corporate } \\
\text { governance corporate } \\
\text { Evidence for UK firms }\end{array}$ & Florackis (2008) & $\begin{array}{l}\text { Ratio of annual sales to total assets } \\
\text { Selling, general \& administrative expense to } \\
\text { sales }\end{array}$ \\
\hline $\begin{array}{l}\text { Agency costs, and } \\
\text { governance mechanisms and Weir } \\
\text { ownership structure in large UK } \\
\text { publicly quoted companies: A }\end{array}$ & $\begin{array}{l}\text { Ratio of sales-to-total assets, } \\
\text { interaction of free cash flows and growth } \\
\text { prospects and } \\
\text { Number of acquisitions }\end{array}$ \\
\hline
\end{tabular}




\begin{tabular}{|l|l|l|}
\hline panel data analysis & \\
\hline $\begin{array}{l}\text { Agency costs, ownership } \\
\text { structures and corporate } \\
\text { governance mechanisms }\end{array}$ & $\begin{array}{l}\text { Singh and Davidson } \\
\text { Iii (2003) }\end{array}$ & $\begin{array}{l}\text { Ratio of annual sales to total assets } \\
\text { Selling, general \& administrative expense to } \\
\text { total sales }\end{array}$ \\
\hline
\end{tabular}

Table 3. ANOVA table for all banks have same agency cost

\begin{tabular}{|c|c|c|c|c|c|}
\hline Metric & F statistic & $\begin{array}{c}1 \% \mathrm{~F} \text { critical } \\
\text { value }>\end{array}$ & $\begin{array}{c}5 \% \% \mathrm{~F} \\
\text { critical value }>\end{array}$ & $\begin{array}{c}10 \% \% \mathrm{~F} \\
\text { critical value }>\end{array}$ & Accept/Reject \\
\hline $\begin{array}{c}\text { Operating expenses to interest } \\
\text { income }\end{array}$ & 19.64 & 2.79 & 2.37 & 1.94486 & Rejected \\
\hline Operating expenses to total loans & 6.12 & 2.79 & 2.37 & 1.94486 & Rejected \\
\hline
\end{tabular}

Table 4. ANOVA table for all banks within the same category

\begin{tabular}{|c|c|c|c|c|c|c|}
\hline Metric & Bank Group & F statistic & $\begin{array}{c}1 \% \mathrm{~F} \\
\text { critical } \\
\text { value }>\end{array}$ & $\begin{array}{l}5 \% \% \mathrm{~F} \\
\text { critical } \\
\text { value }>\end{array}$ & $\begin{array}{c}10 \% \% \mathrm{~F} \\
\text { critical } \\
\text { value }>\end{array}$ & Accept/Reject \\
\hline \multirow{5}{*}{$\begin{array}{l}\text { Operating } \\
\text { expenses to } \\
\text { interest } \\
\text { income }\end{array}$} & Foreign Bank & 8.66 & 1.47 & 1.32 & 1.23 & Rejected \\
\hline & Nationalised Bank & 2.64 & 2.49 & 1.88 & 1.63 & Rejected \\
\hline & New Private Sector & 1.86 & 7.06 & 3.74 & 2.76 & Accepted \\
\hline & Old Private Sector & 14.28 & 2.36 & 1.81 & 1.58 & Rejected \\
\hline & SBI \& Associates & 3.03 & 5.65 & 3.23 & 2.51 & Accepted \\
\hline \multirow{5}{*}{$\begin{array}{l}\text { Operating } \\
\text { expenses to } \\
\text { total loans }\end{array}$} & Foreign Bank & 2.43 & 1.47 & 1.32 & 1.23 & Rejected \\
\hline & Nationalised Bank & 2.64 & 2.49 & 1.88 & 1.63 & Rejected \\
\hline & New Private Sector & 42.27 & 7.06 & 3.74 & 2.76 & Rejected \\
\hline & Old Private Sector & 5.29 & 2.36 & 1.81 & 1.58 & Rejected \\
\hline & SBI \& Associates & 2.77 & 5.65 & 3.23 & 2.51 & Accepted \\
\hline
\end{tabular}

Table 5. ANOVA table for agency cost of bank for study period

\begin{tabular}{|c|c|c|c|c|c|c|}
\hline Metric & Years & F statistic & $\begin{array}{c}1 \% \mathrm{~F} \text { critical } \\
\text { value }>\end{array}$ & $\begin{array}{c}5 \% \% \mathrm{~F} \text { critical } \\
\text { value }>\end{array}$ & $\begin{array}{c}10 \% \% \mathrm{~F} \\
\text { critical value }>\end{array}$ & Accept/Reject \\
\hline \multirow{8}{*}{$\begin{array}{l}\text { Operating } \\
\text { expenses to } \\
\text { interest } \\
\text { income }\end{array}$} & 2013 & 3.27 & 3.48 & 2.68 & 1.99 & Accept \\
\hline & 2012 & 3.29 & 3.48 & 2.68 & 1.99 & Accept \\
\hline & 2011 & 3.05 & 3.48 & 2.68 & 1.99 & Accept \\
\hline & 2010 & 2.3 & 3.48 & 2.68 & 1.99 & Accept \\
\hline & 2009 & 3.14 & 3.48 & 2.68 & 1.99 & Accept \\
\hline & 2008 & 3.42 & 3.48 & 2.68 & 1.99 & Accept \\
\hline & 2007 & 3.48 & 3.48 & 2.68 & 1.99 & Accept \\
\hline & 2006 & 2.33 & 3.48 & 2.68 & 1.99 & Accept \\
\hline
\end{tabular}




\begin{tabular}{|c|c|c|c|c|c|c|}
\hline & 2005 & 0.83 & 3.48 & 2.68 & 1.99 & Accept \\
\hline \multirow{5}{*}{$\begin{array}{c}\text { Operating } \\
\text { expenses to }\end{array}$} & 2013 & 1.55 & 3.48 & 2.68 & 1.99 & Accept \\
\cline { 2 - 7 } total loans & 2012 & 1.5 & 3.48 & 2.68 & 1.99 & Accept \\
\cline { 2 - 7 } & 2011 & 1.26 & 3.48 & 2.68 & 1.99 & Accept \\
\cline { 2 - 7 } & 2010 & 2.33 & 3.48 & 2.68 & 1.99 & Accept \\
\cline { 2 - 7 } & 2009 & 1.56 & 3.48 & 2.68 & 1.99 & Accept \\
\cline { 2 - 7 } & 2007 & 1.69 & 3.48 & 2.48 & 1.99 & Accept \\
\cline { 2 - 7 } & 2006 & 0.79 & 3.48 & 2.68 & 1.99 & Accept \\
\cline { 2 - 7 } & 2005 & 0.61 & 3.48 & 2.68 & 1.99 & Accept \\
\hline
\end{tabular}

Table 5. ANOVA table for agency cost of bank for study period

\begin{tabular}{|c|c|c|c|c|c|c|}
\hline Metric & Years & F statistic & $\begin{array}{c}1 \% \mathrm{~F} \text { critical } \\
\text { value }>\end{array}$ & $\begin{array}{c}5 \% \% \mathrm{~F} \text { critical } \\
\text { value }>\end{array}$ & $\begin{array}{c}10 \% \% \mathrm{~F} \\
\text { critical value }>\end{array}$ & Accept/Reject \\
\hline \multirow{9}{*}{$\begin{array}{l}\text { Operating } \\
\text { expenses to } \\
\text { interest } \\
\text { income }\end{array}$} & 2013 & 3.27 & 3.48 & 2.68 & 1.99 & Accept \\
\hline & 2012 & 3.29 & 3.48 & 2.68 & 1.99 & Accept \\
\hline & 2011 & 3.05 & 3.48 & 2.68 & 1.99 & Accept \\
\hline & 2010 & 2.3 & 3.48 & 2.68 & 1.99 & Accept \\
\hline & 2009 & 3.14 & 3.48 & 2.68 & 1.99 & Accept \\
\hline & 2008 & 3.42 & 3.48 & 2.68 & 1.99 & Accept \\
\hline & 2007 & 3.48 & 3.48 & 2.68 & 1.99 & Accept \\
\hline & 2006 & 2.33 & 3.48 & 2.68 & 1.99 & Accept \\
\hline & 2005 & 0.83 & 3.48 & 2.68 & 1.99 & Accept \\
\hline \multirow{9}{*}{$\begin{array}{l}\text { Operating } \\
\text { expenses to } \\
\text { total loans }\end{array}$} & 2013 & 1.55 & 3.48 & 2.68 & 1.99 & Accept \\
\hline & 2012 & 1.5 & 3.48 & 2.68 & 1.99 & Accept \\
\hline & 2011 & 1.26 & 3.48 & 2.68 & 1.99 & Accept \\
\hline & 2010 & 2.33 & 3.48 & 2.68 & 1.99 & Accept \\
\hline & 2009 & 1.56 & 3.48 & 2.68 & 1.99 & Accept \\
\hline & 2008 & 0.86 & 3.48 & 2.68 & 1.99 & Accept \\
\hline & 2007 & 1.69 & 3.48 & 2.68 & 1.99 & Accept \\
\hline & 2006 & 0.79 & 3.48 & 2.68 & 1.99 & Accept \\
\hline & 2005 & 0.61 & 3.48 & 2.68 & 1.99 & Accept \\
\hline
\end{tabular}

Table 6. Persistence test

\begin{tabular}{|c|c|c|c|c|c|c|c|c|}
\hline \multicolumn{10}{|c|}{ Operating Expenses to Interest Income } \\
\hline Year & WW & WL & LL & LW & \% of Repeat (W or L) & Malkiel Z test & CPR & B\&G Z stat \\
\hline 2013 & 57 & 2 & 43 & 1 & 0.97 & 7.16 & 1225.5 & 5.73 \\
\hline 2012 & 55 & 6 & 38 & 4 & 0.9 & 6.27 & 87.08 & 6.58 \\
\hline 2011 & 58 & 4 & 38 & 3 & 0.93 & 6.86 & 183.67 & 6.58 \\
\hline
\end{tabular}




\begin{tabular}{|c|c|c|c|c|c|c|c|c|}
\hline 2010 & 59 & 4 & 37 & 3 & 0.93 & 6.93 & 181.92 & 6.57 \\
\hline 2009 & 60 & 3 & 37 & 3 & 0.94 & 7.18 & 246.67 & 6.54 \\
\hline 2008 & 57 & 5 & 35 & 6 & 0.89 & 6.6 & 66.5 & 6.53 \\
\hline 2007 & 55 & 5 & 36 & 7 & 0.88 & 6.45 & 56.57 & 6.47 \\
\hline 2006 & 38 & 13 & 30 & 22 & 0.66 & 3.5 & 3.99 & 3.24 \\
\hline \multirow{2}{*}{ Total } & 439 & 42 & 294 & 49 & 0.89 & & & \\
\hline & 824 & & & & & & & \\
\hline \multicolumn{9}{|c|}{ Operating Expenses to Total Loan } \\
\hline Year & $\mathbf{W W}$ & WL & $\mathbf{L L}$ & $\mathbf{L W}$ & \% of Repeat (W or L) & Malkiel Z test & CPR & B\&G Z stat \\
\hline 2013 & 52 & 7 & 38 & 6 & 0.87 & 5.86 & 47.05 & 6.46 \\
\hline 2012 & 54 & 7 & 37 & 5 & 0.88 & 6.02 & 57.09 & 6.49 \\
\hline 2011 & 57 & 5 & 37 & 4 & 0.91 & 6.60 & 105.4 & 6.62 \\
\hline 2010 & 60 & 3 & 38 & 2 & 0.95 & 7.18 & 380.0 & 6.35 \\
\hline 2009 & 60 & 3 & 37 & 3 & 0.94 & 7.18 & 246.7 & 6.54 \\
\hline 2008 & 58 & 4 & 36 & 5 & 0.91 & 6.86 & 104.4 & 6.61 \\
\hline 2007 & 57 & 3 & 38 & 5 & 0.92 & 6.97 & 144.4 & 6.55 \\
\hline 2006 & 52 & 7 & 36 & 8 & 0.85 & 5.86 & 33.43 & 6.25 \\
\hline \multirow{2}{*}{ Total } & 450 & 39 & 297 & 38 & 0.91 & & & \\
\hline & 824 & & & & & & & \\
\hline
\end{tabular}

Note. The number of banks changing category (from winner to loser or vice versa) for next period is equal to the number of banks remaining in the same category.

Table 7. Coefficient of variation for bank categories

\begin{tabular}{|c|c|c|c|c|}
\hline \multicolumn{5}{|c|}{ Operating Expenses to Interest Income } \\
\hline Bank Category & Mean & SD & Covariance & Rank (Ascending Order) \\
\hline Foreign Bank & 0.680 & 1.200 & 1.765 & 4 \\
\hline Nationalised Bank & 0.220 & 0.660 & 3.000 & 5 \\
\hline New Private Sector Bank & 0.340 & 0.160 & 0.471 & 3 \\
\hline Old Private Sector Bank & 0.270 & 0.110 & 0.407 & 2 \\
\hline SBI \& Associates & 0.230 & 0.070 & 0.304 & 1 \\
\hline \multicolumn{5}{|c|}{ Operating Expenses to Total Loan } \\
\hline Bank Category & Mean & SD & Covariance & Rank (Ascending Order) \\
\hline Foreign Bank & 0.0100 & 0.0400 & 4.00 & 1 \\
\hline Nationalised Bank & 0.0048 & 0.0258 & 5.35 & 5 \\
\hline New Private Sector Bank & 0.0049 & 0.0260 & 5.30 & 2 \\
\hline Old Private Sector Bank & 0.0048 & 0.0257 & 5.32 & 4 \\
\hline SBI \& Associates & 0.0049 & 0.0258 & 5.30 & 2 \\
\hline
\end{tabular}




\section{Copyright Disclaimer}

Copyright for this article is retained by the author(s), with first publication rights granted to the journal. This is an open-access article distributed under the terms and conditions of the Creative Commons Attribution license (http://creativecommons.org/licenses/by/3.0/). 